University of Nebraska - Lincoln

DigitalCommons@University of Nebraska - Lincoln

\title{
Remediation of RDX- and HMX-Contaminated Groundwater Using Organic Mulch Permeable Reactive Barriers
}

\author{
Farrukh Ahmad \\ Groundwater Services, Inc., 2211 Norfolk, Suite 1000, Houston, Texas \\ Stephen P. Schnitker \\ US Army Corps of Engineers (USACE), USACE Labs, 420 South 18th Street, Omaha, Nebraska \\ Charles J. Newell \\ Groundwater Services, Inc., 2211 Norfolk, Suite 1000, Houston, Texas
}

Follow this and additional works at: https://digitalcommons.unl.edu/usarmyresearch

Part of the Operations Research, Systems Engineering and Industrial Engineering Commons

\begin{abstract}
Ahmad, Farrukh; Schnitker, Stephen P.; and Newell, Charles J., "Remediation of RDX- and HMXContaminated Groundwater Using Organic Mulch Permeable Reactive Barriers" (2007). US Army Research. 48.

https://digitalcommons.unl.edu/usarmyresearch/48
\end{abstract}

This Article is brought to you for free and open access by the U.S. Department of Defense at DigitalCommons@University of Nebraska - Lincoln. It has been accepted for inclusion in US Army Research by an authorized administrator of DigitalCommons@University of Nebraska - Lincoln. 


\title{
Remediation of RDX- and HMX-contaminated groundwater using organic mulch permeable reactive barriers
}

\author{
Farrukh Ahmad $^{\mathrm{a}, *}$, Stephen P. Schnitker ${ }^{\mathrm{b}, 1}$, Charles J. Newell ${ }^{\mathrm{a}, 2}$ \\ a Groundwater Services, Inc., 2211 Norfolk, Suite 1000, Houston, Texas 77098-4054, USA \\ ${ }^{\mathrm{b}}$ US Army Corps of Engineers (USACE), USACE Labs, 420 South 18th Street, Omaha, Nebraska 68102, USA
}

Received 13 September 2005; received in revised form 1 September 2006; accepted 7 September 2006 Available online 24 October 2006

\begin{abstract}
Organic mulch is a complex organic material that is typically populated with its own consortium of microorganisms. The organisms in mulch breakdown complex organics to soluble carbon, which can then be used by these and other microorganisms as an electron donor for treating RDX and HMX via reductive pathways. A bench-scale treatability study with organic mulch was conducted for the treatment of RDX- and HMX-contaminated groundwater obtained from a plume at the Pueblo Chemical Depot (PCD) in Pueblo, Colorado. The site-specific cleanup criteria of $0.55 \mathrm{ppb}$ RDX and $602 \mathrm{ppb}$ HMX were used as the logical goals of the study. Column flow-through tests were run to steady-state at the average site seepage velocity, using a 70\%:30\% (vol.:vol.) mulch:pea gravel packing to approach the formation's permeability. Significant results included: (1) Complete removal of $90 \mathrm{ppb}$ influent RDX and $8 \mathrm{ppb}$ influent HMX in steady-state mulch column effluent; (2) pseudo-first-order steady-state kinetic rate constant, $k$, of 0.20 to $0.27 \mathrm{~h}^{-1}$ based on RDX data, using triplicate parallel column runs; (3) accumulation of reduced RDX intermediates in the steady-state column effluent at less than $2 \%$ of the influent RDX mass; (4) no binding of RDX to the column fill material; and (5) no leaching of RDX, HMX or reduction intermediates from the column fill material. The results of the bench-scale study will
\end{abstract}

\footnotetext{
* Corresponding author. Tel.: +1 713522 6300; fax: +1 7135228010 .

E-mail addresses: fahmad@gsi-net.com (F. Ahmad), Phillip.S.Schnitker@nwo02.usace.army.mil (S.P. Schnitker), cjnewell@gsi-net.com (C.J. Newell).

1 Tel:: +1 4024444319 .

2 Tel.: +1 7135226300 .
} 
be used to design and implement a pilot-scale organic mulch/pea gravel permeable reactive barrier (PRB) at the site.

(C) 2006 Elsevier B.V. All rights reserved.

Keywords: PRB; RDX; Organic mulch; Groundwater remediation; Biowall

\section{Introduction}

Heterocyclic nitramines, such as hexahydro-1,3,5-trinitro-1,3,5-triazine (RDX) and octahydro-1,3,5,7-tetranitro-1,3,5,7-tetrazocine (HMX), are energetic materials that commonly make up the bulk of modern explosive formulations (ATSDR, 1996). Because of their poor soil sorption properties (Sheremata et al., 1999) and their relatively high solubilities, compared to other energetic materials, these compounds have been found to contaminate groundwater at military facilities where explosive materials are packaged and handled (Spanggord et al., 1980; Oh et al., 2001). Although there are little data to establish their human toxicity at low concentrations, these compounds are generally regarded as possible human carcinogens due to their ability to cause adverse effects in a variety of different organisms, including hepatic tumors in mice (ATSDR, 1996). It has been estimated that there are over 500 military sites where groundwater is contaminated with energetic compounds (Wani et al., 2002). Hence, there is a widespread need to implement remediation technologies to treat RDX and HMX plumes, especially because some of these plumes have migrated off the DoD bases and could threaten public water supplies (St.John, 1998; Hansen et al., 2001).

Both ex situ and in situ processes have been employed for the remediation of RDX- and HMXcontaminated groundwater. Ex situ processes include the treatment of pumped groundwater in granular activated carbon units (Vanderloop et al., 1997; Hansen et al., 2001), anaerobic bioreactors, electrochemical cells, and UV-oxidation reactors, all of which have the disadvantage of high pumping and re-injection costs. In situ processes are generally cheaper and have fewer regulatory limitations. In situ reduction processes using either zero-valent iron (ZVI) (Singh et al., 1999; Oh et al., 2001) or anaerobic biodegradation (Heaston et al., 2001; Davis et al., 2001) have the potential to reduce RDX and HMX. However, disadvantages of high materials expense for ZVI walls and repeated injections for soluble electron donor technologies such as molasses, lactate, and hydrogen-release compound (HRC ${ }^{\circledR}$ ) (Heaston et al., 2001), necessitate the development of a relatively cheap and passive groundwater remediation alternative for treating RDX and HMX.

The introduction of mulch and compost is known to turn aquifers anaerobic, thereby leading to the transformation of electrophilic contaminants via reductive pathways. Mulch and compost have been used as a source of electron donor for chlorinated solvents (Aziz et al., 2001), perchlorate (Perlmutter et al., 2000), and nitrate (Robertson et al., 2000). Mulch has advantages over other electron donors: it is cheaply available, long-lasting (Melillo et al., 1982; Schoemaker et al., 1985; Duryea et al., 1999; Aziz et al., 2001; Lynd et al., 2002), and is naturally present in the environment. Biological reduction of aquifer RDX and HMX contamination (McCormick et al., 1981; Hawari et al., 2000) can be stimulated by allowing contaminated groundwater to pass through an in situ mulch permeable reactive barrier (PRB) that acts as a slow-release source of soluble carbon electron donor. Mulch PRBs operate passively and, therefore, require no aboveground injection system, greatly reducing operating and maintenance costs. Furthermore, mulch is cultured by its own consortium of microorganisms that can supplement the existing bioactivity 
from native RDX- and HMX-degrading microorganisms in a contaminated aquifer. Microorganisms capable of degrading RDX and HMX, such as those of the Clostridia genus and other organisms displaying nitroreductase activity, are generally considered to be ubiquitous in terrestrial environments (Regan and Crawford, 1994; Ederer et al., 1997; Ahmad and Hughes, 2000; 2002; Zhang and Hughes, 2002). Therefore, the acclimation of microorganisms in mulch is unlikely to be a problem in this application of mulch PRBs.

Organic mulch consists of carbon predominantly in the form of complex biopolymers such as lignin and cellulose. Mechanistically, the "slow release" of dissolved organic carbon (e.g., humic acids, fulvic acids, cellobiose) from the mulch matrix occurs via hydrolytic reactions of aerobic and facultative organisms, and from the action of extracellular enzymes of plants and fungi (e.g., laccase, lignin peroxidase, cellulase) (Schoemaker et al., 1985). These reactions consume oxygen to drive the system anaerobic along the flow-path. Subsequently, fermentative metabolic activity of facultative and obligate anaerobic organisms under the oxygen-depleted conditions, results in a dissipation of reducing power through the reoxidation of reduced electron carriers (Ahmad and Hughes, 2000) (Fig. 1). Reoxidation of reduced electron carriers can occur through direct or indirect electron shuttling reactions (e.g., indirectly via quinoid moieties in soil natural organic matter and humic substances (Lovely, 2001)). Such reactions have the ability to reduce electrophilic contaminants such as RDX and HMX. Alternatively, molecular hydrogen can also be produced by acidogenic (i.e., acid generating, a sub-class of fermenters) organisms, which can then be utilized as an electron donor by other organisms.

A site-specific treatability study was devised as the first part of a project to implement and test a pilot-scale mulch PRB for the treatment of RDX- and HMX-contaminated groundwater. The selected site, the SWMU-17 Area of the Pueblo Chemical Depot (PCD) in Pueblo, Colorado, formerly housed a TNT Washout Facility and Discharge System that has been the source of at least

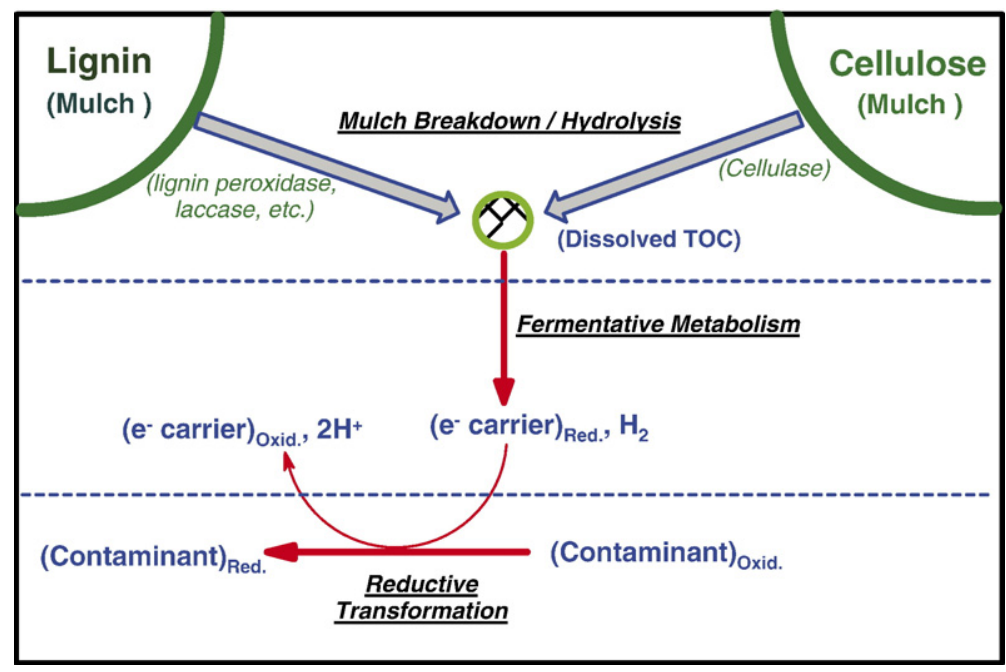

Fig. 1. Schematic depicting the relationship between mulch (i.e., lignin and cellulose) breakdown, fermentative metabolism, and the reductive transformation of electrophilic contaminants such as RDX. Mulch breakdown products are used as electron donors by microorganisms to generate reducing equivalents via substrate-level phosphorylation. The reducing equivalents can directly or indirectly (i.e., via molecular hydrogen generation) reduce strongly electrophilic nitro groups of contaminants like RDX and HMX. 
3 different groundwater plumes containing secondary explosive contaminants. At least one of these plumes has migrated off-base, prompting the Colorado Department of Public Health and Environment (CDPHE) to set cleanup levels for RDX, HMX, and TNT of $0.55 \mathrm{ppb}, 602 \mathrm{ppb}$, and $2 \mathrm{ppb}$, respectively. The SWMU-17 energetics-contaminated groundwater plume selected for the mulch PRB implementation possesses a combination of RDX and HMX contamination, with only RDX exceeding the State-mandated cleanup levels at historically high concentrations of $55 \mathrm{ppb}$ in the source area.

The treatability study conducted for the selected plume involved packed-column flow-through tests. The column flow-through tests used groundwater from the selected site, locally available mulch, and flow rates typical of those observed at the selected site. Since steady-state conditions in column flow-through systems were representative of the pilot-scale PRB operation at the site, they yield critical design parameters for the field implementation of the technology. The specific objectives of the bench-top treatability study were:

1. To test the efficacy of organic mulch as an electron donor to promote the biological reduction of RDX and/or HMX present in groundwater.

2. To determine the rate constants and reaction extent of RDX and/or HMX removal at steadystate.

3. To calculate design parameters for the construction of the mulch PRB for the pilot test that is capable of meeting any applicable regulatory action levels.

4. To monitor the fate and accumulation of any reduction intermediates (e.g., MNX, DNX, TNX) in the treated effluent.

5. To evaluate whether the solid reactive matrix of the mulch PRB can be left in-place following treatment.

\section{Models for column tests}

This section presents the solutions to the advection-dispersion equation used to fit the experimental data from the packed-column flow-through experiments.

\subsection{Tracer tests}

The objective of the tracer tests was to determine the hydrodynamic parameters for each column. The transient flow of a tracer through a column packed with porous media can be described using the one-dimensional advection-dispersion differential equation for a conservative contaminant (Fetter, 1999). Hydrodynamic parameters can be determined by conducting a stepresponse tracer test using a tracer such as chloride, which is both non-reactive and non-sorbing. The change in concentration of the tracer in the column effluent with time can be described by the solution known as Sauty Approximation (Sauty, 1980):

$$
\frac{C}{C_{0}}=\frac{1}{2}\left[\operatorname{ercf}\left(\frac{\mathrm{L}-\mathrm{v}_{\mathrm{x}} \mathrm{t}}{2 \sqrt{\mathrm{D}_{\mathrm{L}} \mathrm{t}}}\right)\right]
$$

where,

Initial conditions $C(x=L, t \leq 0)=0 ; C(x=0, t=0)=0$

Boundary conditions $C(x=0, t>0)=C_{0} ; C(x=\infty, t>0)=0$ 


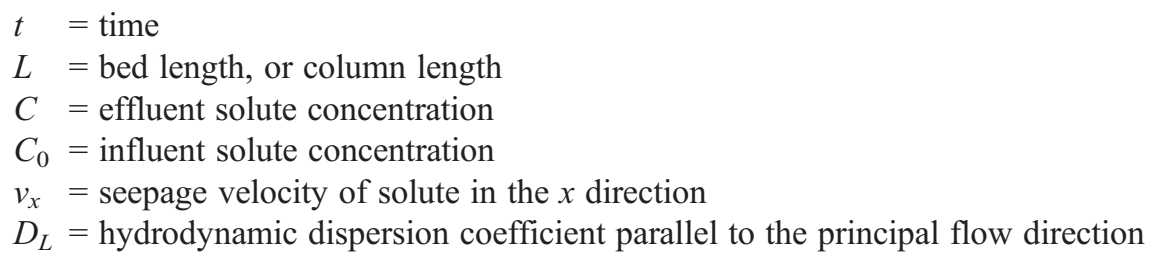

Eq. (1) is valid for higher Peclet numbers (i.e., greater than 10) as it is an approximation of the step-response solution of the advection-dispersion equation for a conservative substance, where the contribution from the second term of the solution is assumed to be negligible (Sauty, 1980; Fetter, 1999). Under high Peclet number conditions, the effects of molecular diffusion become negligible compared to the advection and the longitudinal hydrodynamic dispersion coefficient, $D_{L}$, can be effectively described using the following expression:

$$
D_{L}=\alpha_{L} v_{x}
$$

where,

$$
\alpha_{L}=\text { longitudinal dispersivity }
$$

The experimental tracer data can be fitted using Eq. (1) to yield the necessary hydrodynamic dispersion coefficient, $D_{L}$. The longitudinal dispersivity, $\alpha_{L}$, can then be determined by using the seepage velocity in Eq. (2).

\subsection{Degradation kinetics tests}

Reaction kinetics are studied by running the target contaminant through the column until the column reaches steady-state. Steady-state is reached when the aqueous contaminant concentration has become time-independent at every point along the length of the column. At that point in time, samples are collected along the length of the column and analyzed for the target contaminant(s). The data from such analyses is used to plot a steady-state bed profile concentration profile (i.e., plot of $C / C_{0}$ versus bed length, $x$ ). The empirical bed profile can be fitted with a mathematical steady-state bed-profile solution (vanGenuchten and Alves, 1982) to the one-dimensional advection-dispersion equation for a contaminant that is non-sorbing and is undergoing a first-order decay (Sauty, 1980; Fetter, 1999; Charbeneau, 2000) to determine the pseudo-first-order rate constant, $k$ :

$$
\frac{C}{C_{0}}=\exp \left[\left(\frac{x}{2 D_{L}}\right)\left(v_{x}-\sqrt{v_{x}^{2}+4 k D_{L}}\right)\right]
$$

where,

Boundary conditions: $C(x=0)=C_{0} ; \mathrm{d} C / \mathrm{d} x(x=\infty)=0$

$k=$ pseudo-first-order rate constant (dimensions of inverse time)

$x=$ dimension in the direction of flow 
An approach more commonly used in PRB literature is the plotting of the column bed profile data as a function of bed residence time using a direct first-order kinetic model (Gavaskar et al., 1998; USEPA, 1998; Gavaskar et al., 2000), to yield $k$ as the slope:

$$
\operatorname{Ln}\left(\frac{C}{C_{0}}\right)=-\mathrm{k} t_{R}
$$

where,

$t_{R}=$ bed residence time $=\mathrm{V}_{\mathrm{p}} / Q=$ pore volume to bed length of $x /$ volumetric flowrate.

Eq. (4) has two significant drawbacks. First, it generates slightly more optimistic answers for the degradation rate constants as this equation does not account for dispersion. Second, a problem occurs in applying the graphical approach of Eq. (4) to zero values, such as those assigned to nondetects with finite detection limits. Non-detects can occur along the length of the column under conditions of strong biodegradation activity. In such cases, it is more suitable to apply an iterative approach involving Eq. (3) to determine the pseudo-first-order rate constant.

\section{Materials and methods}

\subsection{Materials}

\subsubsection{Chemicals}

All chemicals used in the study were graciously provided by Dr. Pedro Alvarez of the Department of Civil and Environmental Engineering at Rice University, Houston, Texas.

\subsubsection{Experimental media}

An inquiry into the cost and availability of a variety of mulch types revealed pine and pine bark mulches to be the most favorable choices in Pueblo and Colorado Springs ( $<40$ miles from Pueblo), Colorado, the location of the selected site. Hence, this was the type of mulch selected for the experiment. Commercially-available mixture of pine and pine bark mulch was purchased from a local Houston, Texas, vendor. The mulch was manufactured by Garden Plus of New Waverly, Texas. Mulch was sieved so that particles passing through a No. 4 sieve (approx. $4.75 \mathrm{~mm}$ ) and retained by the No. 18 sieve (approx. $1 \mathrm{~mm}$ ) were collected in Ziploc ${ }^{\circledR}$ bags and stored in a refrigerator $\left(4^{\circ} \mathrm{C}\right)$ for later use. The pea gravel used in the columns was also obtained from a commercial vendor local to the Houston area. The pea gravel used was fairly uniform in size, but was sieved between a 9.5mm mesh-sieve and a No. 4 sieve, to exclude a few very large and very small particles.

\subsubsection{Site environmental media}

Approximately 60 gal of site groundwater was collected (3 drums, 20-gal each) from well CSPDPW3 18 by the PCD facility contractor, Earth Tech Inc., and was shipped to Houston. This well is located in the source area of the target plume selected for the eventual pilot-scale field demonstration. The groundwater-bearing unit depth at which CSPDPW318 well screen is located is naturally aerobic. Therefore, no special precautions were taken during shipping. Site soil samples were collected by GSI using a hand-auger at a depth of approximately $8 \mathrm{ft}$ bgs at a location approximately 30-40 ft downgradient of well CSPDPW318. This depth interval was selected because a significant amount of moisture was encountered in it, indicating that this depth might be 
the initiation of the capillary zone. However, chemical analysis of the collected soil sample did not show the presence of any munitions above the $0.1 \mathrm{ppm}$ (i.e., $1 \mathrm{mg} / \mathrm{kg}$ ) detection limit for the method. Although suitable for use in the control column, clean soil is likely to show some initial removal at the start of the column kinetics experiment. Such effects can be caused by non-equilibrium sorptive processes (i.e., mass transfer) between the clean soil and the contaminated groundwater, but these processes would be expected to diminish over time as the system reaches equilibrium.

\subsubsection{Hardware}

Glassware used in the column experiments consisted of five columns and four $60-\mathrm{mL}$ flowthrough/gas-venting vessels. The glassware was designed by Dr. Ahmad and fabricated by Specialty Glass, Inc., of Houston, Texas. All columns had dimensions of a 46-mm internal ID and $80 \mathrm{~cm}$ in length, were constructed of 4-mm-thick glass, and had low-pressure but water-tight GPI screw cap ends with 1/8-inch tubing adapters. Each mulch column had a total of 10 side sampling ports (see Fig. 2). The first 6 sampling ports were located at 5-cm intervals along the length of the column. The remaining 4 ports were located at $10-\mathrm{cm}$ intervals along the remaining length of the column. The sampling ports had 10-mm-diameter (3-mm-thick lip) flange openings. The sampling ports were sealed by crimping on HPLC crimp seals containing 3-layer TFE/Silicone/TFE liners (Alltech Chromatography, Deerfield, IL). The two control columns had no side sampling ports.

The 60 -mL flow-through/gas-venting vessels maintained a constant hydraulic head over the column, with the influent liquid coming in from the bottom and overflowing out of a side-arm (see Fig. 2). A valved gas-venting port was located $3-4 \mathrm{~cm}$ above the side liquid effluent port to allow the release of pressure from any gas accumulation. A $25-\mathrm{mm}$ opening at the top of the vessel allowed the suspension of $\mathrm{pH}$ and redox probes through a one-hole rubber stopper.

The peristaltic pump used in the study consisted of a Masterflex ${ }^{\circledR}$ L/S Standard Brushless Digital drive (Model C-07523-50) with a low-pulsing (i.e., 8-roller) 4-cartridge pump head

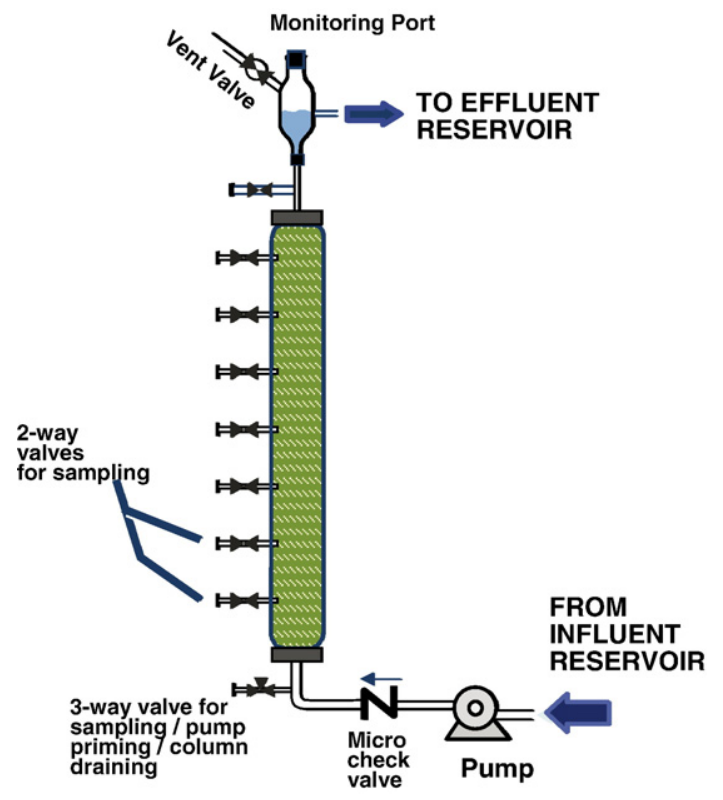

Fig. 2. Experimental setup for the column study showing the flow scheme through a single mulch column. 
(Model C-07519-20), both by Cole-Parmer of Vernon Hills, Illinois. Masterflex ${ }^{\circledR}$ microbore Viton ${ }^{\circledR}$ tubing was used in the pump head cartridges and on the lower-pressure side (influent reservoir end) of the pump. Stainless steel solvent filters (Upchurch Scientific) were used at the inlet end of the tubing. On the higher pressure side of the pump head, micro-tubing check valves were installed. These check valves had a cracking pressure of $0.5 \mathrm{psi}$ and had a back-pressure resistance of $>50$ psi (Cole Parmer part no. C-06473-17), and prevented backflow from the columns at low pumping rates. All other tubing used in the study was $1 / 8$-inch-ID rigid black polyvinyl tubing.

A chloride ion-selective electrode (Cole-Parmer part no. C-27504-08) was used during the chloride tracer test. Single-junction $\mathrm{pH}$ and ORP probes, also from Cole-Parmer, were used during the kinetics study. A Fisher Scientific pH meter (Accumet Model no. 10) was used for taking the $\mathrm{pH}$ and ORP readings.

\subsection{Methods: initial media characterization}

All media used in the experiment was put through an analytical regimen to establish baseline conditions. Aqueous analyses conducted on site groundwater included munitions analysis using the US Army Corps of Engineers (USACE) Environmental Research and Development Center (ERDC) Standard Operating Procedure (SOP) M-8330-ECBO-OA (hereafter designated as "SW8330M"), common anion analysis using method SW846 Method 9056, and dissolved Total Organic Carbon (TOC) analysis by SW846 Method 9060. Additionally, analysis using a field ferrous iron method, HACH 8146, was also conducted on the site groundwater samples. The site soils used in the control columns also underwent munitions analysis using Method SW-8330M. Note that USACE Method SW-8330M is an adaptation of SW846 Method 8330 with an added solid phase extraction (SPE) step in the sample preparation phase that allows very low detection limits (0.08 ppb for RDX and HMX from a 500-mL sample).

The mulch was analyzed for chemical parameters such as total nitrogen, phosphorus, potassium, calcium, magnesium, sulfur, cation exchange capacity, crude protein, and forage analyses, to determine the lignin, cellulose, and hemicellulose content. The analyses were performed by the University of Wisconsin Forage Analysis Labs using standard American Society of Agronomy (ASA) methods.

Geophysical testing was performed by PTS Labs (Houston, Texas) on three types of potential mulch beds: (1) sieved mulch samples (100\%); (2) 70\%:30\% mulch:pea gravel (vol.:vol.) mixture; and, 50\%:50\% mulch:pea gravel (vol.:vol.) mixture. The objective of this exercise was to evaluate the changes in porosity (American Petroleum Institute [API] Method RP40), permeability, and hydraulic conductivity (American Society for Testing and Materials [ASTM] Standard Method D5084) with the changing composition.

\subsection{Methods: column tracer tests}

\subsubsection{Experimental setup}

The 70\%:30\% mulch:pea gravel (volume:volume) mixture was selected for packing the columns. This combination provides a similar porosity as the 50\%:50\% (vol.:vol.) mixture, while supplying a substantially higher level of electron donor. The columns were dry-packed with intermittent tapping of the column wall (i.e., after adding every 3-4 cm column-length of solids). This procedure allowed some settling and compaction of the bed. No other bed compaction procedure was employed. The dry packing procedure described is representative of the mulch 
adding procedure that will likely be employed in the PRB construction during the field demonstration. Screened-gaskets (filter hose washers by L.G. Sourcing of North Wilkesboro, North Carolina) were used inside caps of the columns to keep any small particles out of the tubing. The control column was dry-packed with site soils, after creating a 2-cm-deep pea gravel bed at the bottom of the column (for trapping fines). A similar sized gravel bed was also created at the top of the control column, towards the end of its packing.

Each column was set up with the sample flow-through vessel as shown in Fig. 2. A total of three packed mulch columns (named M1, M2, and M3) and two packed control columns were created for the study (note: only one control column was utilized). The influent line from the pump, the effluent line to the waste reservoir, and the line to the flow-through vessel were connected for each mulch column prior to filling it with liquid. Tracer tests were performed sequentially for each mulch column. Note that the same flow-calibrated pump cartridge and influent line were used for all tracer tests to maintain a consistency of flow between the tests. Chloride was used as the tracer in the step response tracer test. Two gallons of $102 \mathrm{mg} / \mathrm{L}$ chloride solution was prepared in distilled de-ionized (DDI) water.

\subsubsection{Experimental operation}

The porosity of each column was determined prior to initiating each tracer test. Columns were filled in the upflow mode at an average flowrate of $3 \mathrm{~mL} / \mathrm{min}$ with DDI water to displace any air and to determine the column porosity. Once the porosity had been determined, the flowrate was increased to approximately $4.17 \mathrm{~mL} / \mathrm{min}(250 \mathrm{~mL} / \mathrm{h})$ to test the system for any leaks. The DDI water was run through each column at the $250 \mathrm{~mL} / \mathrm{h}$ tracer test flowrate for approximately one pore volume. The pump was stopped at this point and the influent line was changed to the tracer reservoir. The flow to the column was bypassed at the 3-way valve to purge the influent lines with the tracer solution. A 5-point calibration of the chloride probe was performed while the line was purging.

The tracer test was initiated by turning on the flow to the column at the 3 -way valve at the column inlet. For column M1, large volume (i.e., $25 \mathrm{~mL}$ ) samples were collected from the sampling port between the column and the flow-through vessel at 15-min intervals. Approximately $5 \mathrm{~mL}$ volume of each effluent sample was used for measuring the chloride probe reading, and the rest was utilized for chloride ion analysis using the ion chromatography method SW-9056. An excellent correlation between the two different methods was obtained. Hence, for columns M2 and M3, the chloride ion concentration was measured in real time using only the chloride ion selective electrode suspended in the flow-through apparatus. Five-point chloride probe calibrations were performed again at the conclusion of each column tracer test. The tracer tests were run for approximately 2 pore volumes through each column. Each column was flushed with 2 pore volumes of DDI water upon completion of its tracer test.

\subsection{Methods: column kinetics study}

\subsubsection{Experimental setup}

Two of the three site groundwater drums (20-gal ea.) were spiked with RDX to give an approximate final concentration of $90 \mathrm{ppb}$ and were mixed. The drums were allowed to sit over a weekend before they were sampled $(500 \mathrm{~mL}$, amber-colored glass bottles). The samples were analyzed by USACE Labs in Lincoln, Nebraska, using Method SW8330M.

Two-way polycarbonate Luer lock valves (Cole-Parmer) were attached to 1.5-inch-long 18-gauge needles (Alltech Chromatography). The syringe portions of these assemblies were pushed into each $10-\mathrm{cm}$ interval side port of the packed mulch columns for bed profile sampling. The mulch and 
control columns were covered in foil to shield them from light. The pump flowrate and cartridges were calibrated to yield a flowrate of approximately $0.35 \mathrm{~mL} / \mathrm{min}(21 \mathrm{~mL} / \mathrm{h})$, which resulted in an approximate seepage velocity of $2.5 \mathrm{~mL} / \mathrm{h}$ through the mulch columns. The 4 columns (i.e., Control, M1, M2, and M3) were run in parallel with an independent pump cartridge feeding the contaminated groundwater to each column. The reason for running triplicate mulch columns in the kinetics study was to gauge the extent of experimental error introduced into the kinetics test.

\subsubsection{Experimental operation}

The column kinetics test was run for a little over 8 weeks. Control column aqueous influent and effluent samples, together with mulch column bed profile samples $(10 \mathrm{~cm}, 30 \mathrm{~cm}, 50 \mathrm{~cm}$, and $80 \mathrm{~cm}$ side ports) were collected once 10, 20, 30, 37, and 44 pore volumes had passed through each column. Redox and $\mathrm{pH}$ measurements in the influent reservoir and the flow-through vessels were also taken at each sampling interval, except for the first interval.

The transient bed profile samples collected were typically $5 \mathrm{~mL}$ or greater in volume in order to meet a minimum detection limit (MDL) of $5 \mathrm{ppb}$ at the 5-mL sample volume. Larger volume bed profile samples would have produced lower detection limits for the analysis, but the collection of such samples was impractical given the slow flowrate $(0.35 \mathrm{~mL} / \mathrm{min})$ for the system. Large volume samples would have also masked any transient effects in the column bed profile.

Samples were analyzed for munitions compounds using a method adapted from the USACE SW-8330M method. Note that the sample volume of $1.5 \mathrm{~mL}$ was used for the 30 -pore volume round in conjunction with a different sample cleanup procedure attempted at USACE ERDC. Unfortunately, the procedure produced poor internal standard recovery in the results; therefore, this round of samples was not used in determining the steady-state condition of the column. The attainment of steady-state conditions was monitored by comparing curve fits (Eq. (3)) and regression coefficients (between data and model curves) for data from consecutive sampling events. Once steady state conditions had been achieved, effluent lines from the mulch columns were placed in $1 \mathrm{~L}$ amber bottles for large volume sample collections. The large volume steady state samples were analyzed for RDX, HMX, and intermediates analysis using Method SW$8330 \mathrm{M}$ at a detection limit lower than the site cleanup level for RDX.

\subsection{Methods: column bed post-steady-state waste characterization}

Once the kinetics experiment was completed, one pore volume of DDI water was passed through the mulch columns at twice the kinetic experiment flowrate to remove pore water containing residual RDX from the packed beds. Following this step, each of the mulch columns was drained. Two solid bed samples, 10-20 cm bed depth and 60-70 $\mathrm{cm}$ bed depth (measured from the influent end), were removed from column M2 and were analyzed by USACE ERDC Labs for SW-8330M solid sample analysis and TCLP-leachate analysis (SW846 SW-1311 followed by SW-8330M).

\section{Results and discussion}

\subsection{Initial characterization}

\subsubsection{Site groundwater}

Inorganic analyses of the site groundwater from well CSPDPW-318 confirmed the low nitrate, ferrous iron, and TOC concentrations (Table 1) that had been determined previously around this 
Table 1

Initial characterization data for site groundwater used in the column study

\begin{tabular}{|c|c|c|c|c|}
\hline Parameter & MDL & Site groundwater (Drum 1) & Site groundwater (Drum 2) & Units \\
\hline Total Organic Carbon & 0.36 & 3.78 & 3.44 & $\mathrm{mg} / \mathrm{L}$ \\
\hline Sulfate & 40.5 & 615 & 613 & $\mathrm{mg} / \mathrm{L}$ \\
\hline Nitrate-nitrogen & 0.057 & 0.818 & 0.777 & $\mathrm{mg} / \mathrm{L}$ \\
\hline Ferrous Iron & 0.019 & ND & ND & $\mathrm{mg} / \mathrm{L}$ \\
\hline RDX & 0.1 & 19.3 & 18.1 & $\mu \mathrm{g} / \mathrm{L}$ \\
\hline MNX & 0.1 & 0.61 & 0.66 & $\mu \mathrm{g} / \mathrm{L}$ \\
\hline DNX & 0.1 & ND & ND & $\mu \mathrm{g} / \mathrm{L}$ \\
\hline TNX & 0.1 & ND & ND & $\mu \mathrm{g} / \mathrm{L}$ \\
\hline HMX & 0.1 & 9.03 & 8.24 & $\mu \mathrm{g} / \mathrm{L}$ \\
\hline 2,4,6-Trinitrotoluene (TNT) & 0.1 & ND & ND & $\mu \mathrm{g} / \mathrm{L}$ \\
\hline $\begin{array}{l}\text { 4-Amino-2,6- } \\
\text { dinitrotoluene }\end{array}$ & 0.1 & ND & ND & $\mu \mathrm{g} / \mathrm{L}$ \\
\hline $\begin{array}{l}\text { 2-Amino-4,6- } \\
\text { dinitrotoluene }\end{array}$ & 0.1 & ND & ND & $\mu \mathrm{g} / \mathrm{L}$ \\
\hline 2,6-Dinitrotoluene (2,6-DNT) & 0.1 & ND & ND & $\mu \mathrm{g} / \mathrm{L}$ \\
\hline 2,4-Dinitrotoluene $(2,4$-DNT) & 0.1 & ND & ND & $\mu \mathrm{g} / \mathrm{L}$ \\
\hline 1,3,5-Trinitrobenzene (TNB) & 0.1 & ND & ND & $\mu \mathrm{g} / \mathrm{L}$ \\
\hline Tetryl & 0.1 & ND & ND & $\mu \mathrm{g} / \mathrm{L}$ \\
\hline
\end{tabular}

The groundwater was stored in two 20-gal drums and was spiked with RDX to yield a final aqueous RDX concentration of $90.6 \mu \mathrm{g} / \mathrm{L}$ and $83.6 \mu \mathrm{g} / \mathrm{L}$ in Drums 1 and 2, respectively, prior to the initiation of the study.

location at the Pueblo Chemical Depot (PCD). One surprising result was the high level of sulfate $(>600 \mathrm{mg} / \mathrm{L})$ found in the groundwater. This finding is not a deterrent to the reduction of munitions present in the groundwater via electron transfer/shuttling reactions; sulfate ions are less electrophilic than nitro substituents and nitrate ions, and have been shown in some cases to promote munitions reduction (Davis et al., 2001). Hence, sulfate reducing conditions would be expected to occur from any excess reducing equivalents, once the nitro functionalities have been removed in the system via reduction.

Munitions analysis using method SW-8330M (Table 1) revealed RDX concentrations to be between 18.1 to $19.3 \mathrm{ppb}$, significantly lower than the $>50 \mathrm{ppb}$ concentrations that have been observed in this well in the past. However, the measured concentrations were well above the $0.55 \mathrm{ppb}$ safe level mandated for this facility by the CDPHE. Following initial analysis, the concentrations of RDX in Drums 1 and 2 were spiked with the intention of bringing the concentrations up to $90 \mathrm{ppb}$. Reanalysis showed the RDX concentrations to be 90.6 and $83.6 \mathrm{ppb}$ in Drums 1 and 2, respectively. Other munitions components in the groundwater were limited to MNX (trace levels around 0.6 ppb) and HMX (8.24 to $9.03 \mathrm{ppb).} \mathrm{The} \mathrm{trace} \mathrm{levels} \mathrm{of} \mathrm{MNX,} \mathrm{the}$ first reduction product of RDX, are indicative of mild reductive bioactivity already present in the aquifer. Other munition compounds and their co-contaminants and degradation products typically found in groundwater at other locations on PCD (e.g., TNT, DNTs, TNB), were not detected in groundwater from this location.

\subsubsection{Mulch}

Results from the chemical/forage analysis of the sieved mulch used in the column packing are presented in Table 2. First, the nitrogen-to-phosphorus nutrient ratio (N:P) obtained for the mulch was roughly 7:1, which is higher than most organic-rich top soils (Brady, 1974; Bowen, 1979; Schacklette and Boerngen, 1984; Sposito, 1989) (5:1), and is slightly higher than slightly higher than 
Table 2

Data from forage and nutrient analysis of mulch used in the column study

\begin{tabular}{lcc}
\hline Parameter & Result & Units \\
\hline Total nitrogen & 0.16 & $\%$ Dry weight \\
Total phosphorus & 0.022 & $\%$ Dry weight \\
Total potassium & 0.14 & $\%$ Dry weight \\
Total calcium & 0.514 & $\%$ Dry weight \\
Total magnesium & 0.057 & $\%$ Dry weight \\
Total sulfur & 0.028 & $\%$ Dry weight \\
Cation exchange capacity & 88 & meq/100 g \\
Crude protein & 1.81 & $\%$ Dry weight \\
Acid detergent fiber (ADF) & 85.91 & $\%$ Dry weight \\
Neutral detergent fiber (NDF) & 89.67 & $\%$ Dry weight \\
Lignin & 52.56 & $\%$ Dry weight \\
Cellulose & 33.35 & \% Dry weight \\
Hemicellulose & 3.76 & \% Dry weight \\
\hline
\end{tabular}

Table includes cation exchange capacity (CEC) data for the mulch as well.

the mean value observed in a study that used 6 different types of mulch (Duryea et al., 1999) (6:1). The N:P value is at par with plant uptake values found in agricultural soil (Cresser et al., 1993).

Second, the cation exchange capacity (CEC) of the mulch, which reflects its ability to retain positively charged nutrients, was found to be $88 \mathrm{meq} / 100 \mathrm{~g}$. This value is in the range of typical organic-rich agricultural soil values of 50-100 meq/100 g (Bohn et al., 2002); however, it is lower than the typical soil natural organic matter (NOM) and compost range of 100-300 meq/100 g. The lower CEC value is also favorable for producing fewer interactions with energetic materials, especially nitroaromatics, which display weak cation exchange interactions with soil.

Finally, Acid and Neutral Detergent Fiber (ADF and NDF) analyses, and lignin analysis, allowed the calculation of mass fractions of cellulose (i.e., cellulose $=\mathrm{ADF}-$ Lignin) and hemicellulose (i.e., hemicellulose $=\mathrm{NDF}-\mathrm{ADF}$ ) in the mulch. Generally, the availability of carbon decreases as one moves from cellulose, to hemicellulose, and then to lignin (Duryea et al., 1999). Lignin is the most recalcitrant of the three carbon fractions in mulch because of its polyaromatic nature, and, therefore, lends structural integrity to the overall mulch. The lignin content of the mulch was $52.56 \%$, slightly higher than the pine bark mulch value reported in literature (Duryea et al., 1999) (46\%). The higher value might have been brought about by the sieving of the mulch, which removed most of the fine materials from the mulch. The structural strength of the mulch was later enhanced further by adding pea gravel to the mulch column packing. Perhaps the most important result from the mulch analysis was the relatively high cellulose value ( $>33 \%$ by mass). This value represents the fraction of available carbon in the mulch that can be degraded to release dissolved organic carbon under both aerobic and anaerobic conditions (Lynd et al., 2002; Leschine, 2005). Results presented in Table 2 are essential for matching the mulch used in the study with mulch available in the field, so that similar or better degradation kinetic rates can be achieved in the field.

Next, the physical characteristics of 3 mulch:pea gravel mixtures are presented in Table 3 . As expected, the bulk and grain densities increased with an increasing fraction of the gravel. The total porosity dropped drastically when pea gravel content was increased from $0 \%$ to $30 \%$; however, a 50\%:50\% mulch:pea gravel mixture resulted in an insignificant change in total porosity from the previous mark. Conversely, the change in hydraulic conductivity of the packing material increased by over $55 \%$, with every decrease in mulch content and subsequent increase in pea 
Table 3

Geophysical characterization of 3 different dry-packed 6-inch sleeves of mulch: pea gravel volumetric mixtures

\begin{tabular}{|c|c|c|c|c|}
\hline Parameter & Method & $\begin{array}{l}\text { 100\%:0\%, mulch:pea } \\
\text { gravel (vol.:vol.) }\end{array}$ & $\begin{array}{l}70 \%: 30 \%, \text { mulch:pea } \\
\text { gravel (vol.:vol.) }\end{array}$ & $\begin{array}{l}50 \%: 50 \% \text {, mulch:pea } \\
\text { gravel (vol.:vol.) }\end{array}$ \\
\hline Sample orientation & - & Vertical & Vertical & Vertical \\
\hline $\begin{array}{l}\text { Moisture content } \\
\text { (\% bulk weight })\end{array}$ & $\begin{array}{l}\text { ASTM } \\
\text { D2216 }\end{array}$ & 77.6 & 17.1 & 8.7 \\
\hline $\begin{array}{l}\text { Bulk density } \\
\qquad\left(\mathrm{g} / \mathrm{cm}^{3}\right)\end{array}$ & $\begin{array}{l}\text { API } \\
\text { RP40 }\end{array}$ & 0.34 & 1.1 & 1.21 \\
\hline $\begin{array}{l}\text { Grain density } \\
\qquad\left(\mathrm{g} / \mathrm{cm}^{3}\right)\end{array}$ & $\begin{array}{l}\text { API } \\
\text { RP40 }\end{array}$ & 1.37 & 2.12 & 2.31 \\
\hline $\begin{array}{l}\text { Total porosity } \\
\text { (\% bulk volume) }\end{array}$ & $\begin{array}{l}\text { API } \\
\text { RP40 }\end{array}$ & 75.3 & 48.1 & 47.6 \\
\hline $\begin{array}{l}\text { Air filled porosity } \\
\text { (\% bulk volume) }\end{array}$ & $\begin{array}{l}\text { API } \\
\text { RP40 }\end{array}$ & 49.1 & 29.2 & 37 \\
\hline $\begin{array}{l}\text { Total pore fluid saturation } \\
\text { ( } \% \text { pore volume) }\end{array}$ & $\begin{array}{l}\text { API } \\
\text { RP40 }\end{array}$ & 34.8 & 39.2 & 22.2 \\
\hline $\begin{array}{l}\text { Effective permeability to water } \\
\text { (milli-Darcy) }\end{array}$ & $\begin{array}{l}\text { ASTM } \\
\text { D5084 }\end{array}$ & 1,412 & 2,230 & 3,694 \\
\hline $\begin{array}{l}\text { Effective hydraulic } \\
\text { conductivity }(\mathrm{cm} / \mathrm{s})\end{array}$ & $\begin{array}{l}\text { ASTM } \\
\text { D5084 }\end{array}$ & $1.35 \mathrm{E}-03$ & $2.10 \mathrm{E}-03$ & $3.49 \mathrm{E}-03$ \\
\hline
\end{tabular}

gravel content of the mixture. Still, the highest effective hydraulic conductivity obtained with the 50\%:50\% mulch:pea gravel mixture did not match the average hydraulic conductivity value of $6 \mathrm{E}-03 \mathrm{~cm} / \mathrm{s}$ in the vicinity of well CSPDPW318 (mean of 6 slug tests at 2 nearby wells). Despite the higher hydraulic conductivity obtained with the 50\%:50\% mixture, the 70\%:30\% pea gravel mixture was chosen for packing columns because of its higher level of available carbon. At the time of the study, mulch PRB technology was only 6 years old (Aziz et al., 2001); a higher volumetric concentration of organic mulch in the packing mixture was perceived to contribute the longevity of the future implementation and outweigh any hydraulic concerns at the site.

\subsection{Column tracer tests}

Prior to initiating the tracer breakthrough tests, each mulch column was slowly filled with DDI water using a 2-L measuring cylinder as an influent reservoir. Once a column had been filled, the difference in water level in the influent reservoir was measured and the porosity was calculated using the dimensions of the apparatus. The total porosity values determined are presented in Table 6 . These ranged between 50 and $52 \%$. The values compared well with a $48.1 \%$ value determined by an off-site lab for a 6-inch sleeve packed with the 70\%:30\% mulch:gravel mix (Table 3). Note that effective or air-filled porosity of the dry mulch/pea gravel mixture was also measured (Table 3 ) but proved to be an unsuitable curve-fitting parameter compared to the total porosity. It is likely that once the mulch is completely hydrated it becomes permeable to water, contributing to the overall pore volume of each column. Volume expansion in the mulch bed is visible to the naked eye, if a mulch bed is left unconstrained on one end (Duryea et al., 1999). It is further evidenced in the behavior of organic mulch when it is suspended in a jar of water; the mulch initially floats on the surface of the water and eventually sinks once it is hydrated.

Chloride tracer breakthrough tests were conducted for the mulch columns using a tracer solution of $102 \mathrm{mg} / \mathrm{L}$ as chloride. While running the first test, for column M1, split samples were collected, which were analyzed by both a chloride ion-selective probe and SW-9056 (ion 
chromatography method). A comparison of the results from the two different measurement techniques yielded a correlation coefficient, $r^{2}$, of 0.98 . As a result, the tracer tests for columns M2 and M3 were performed only with an inline measurement of the column effluents with the ion-selective electrode.

Flow and packing parameters for each column's tracer tests are listed in Table 4. Based on the column packing characteristics and the tracer solution flowrate (roughly $250 \mathrm{~cm}^{3} / \mathrm{h}$ ), the seepage velocity during the test ranged between 29 and $29.6 \mathrm{~cm} / \mathrm{h}$. At these high seepage velocities, molecular diffusion effects are negligible The longitudinal dispersivity $\left(\alpha_{L}\right)$ was determined using the column-specific seepage velocities using a combination of Eqs. (1) and (2) as described earlier. The $\alpha_{L}$ values that generated the "best-fit" model curve to the each dataset are presented in Table 4. Tracer breakthrough data and the final model curves are presented in Fig. 3A through $C$ for columns M1 through M3, respectively. Following the iterative curve-fitting procedure mentioned in the previous paragraph, dispersivity values of $4.6,1.8$, and $2.3 \mathrm{~cm}$ were determined for columns M1, M2, and M3, respectively (Table 4).

Considering the fairly consistent conditions of operation for the three tests, the tracer test data for column M1 displayed an uncharacteristically higher degree of dispersion than the other two columns. A possible reason for the relatively high dispersivity value for column M1 could be the distinct effluent sampling procedure used in the tracer test for this column. Effluent samples collected from column M1 were approximately $25 \mathrm{~mL}$ in volume, much larger than the typical $5 \mathrm{~mL}$ samples from the other two columns. Collection of high sample volumes possibly caused a back-dilution from fluid present downstream in the flow-through vessel.

\subsection{Column kinetics study}

Appreciable removals of RDX were not anticipated in the mulch columns until approximately 60 pore volumes had passed through each column. This estimate of minimum-time-to-steady state was based on Wani et al. (2002), who used clean aquifer solids with an initially low level of indigenous microorganisms. Their transient degradation results most likely involved a slow buildup of the microorganism population in their columns in the presence of a variety of supplied carbon sources. Contrary to Wani et al.'s findings, early sampling (I.e., at 10 pore volumes) of the mulch columns showed significant removals of RDX from the first sampling event. The rapid removal can be explained by relatively high levels of microorganisms present in the mulch at the start of the experiment (crude protein of $1.81 \%$ dry weight of mulch, Table 2 ) relative to typical aquifer solids.

Initial sampling and analysis of the mulch columns (i.e., at 10 and 20 pore volumes) was performed with the intention of assessing matrix effects in the mulch leachate so that RDX could be properly quantified. However, when the 10-pore volume results showed a complete removal of

Table 4

Summary of key parameters and results for the hydrodynamic tracer test conducted on the packed mulch/pea gravel columns

\begin{tabular}{lccc}
\hline Parameter & Column M1 & Column M2 & Column M3 \\
\hline Flowrate $(Q), \mathrm{cm}^{3} / \mathrm{h}$ & 248.4 & 250.2 & 246.0 \\
Total Porosity $(\eta), \%$ bulk bed volume & 51 & 52 & 50 \\
Pore Volume $\left(V_{p}\right), \mathrm{cm}^{3}$ & 678.1 & 691.4 & 664.9 \\
Seepage velocity $\left(v_{x}\right), \mathrm{cm} / \mathrm{h}$ & 29.3 & 29.0 & 29.6 \\
Longitudinal dispersivity $\left(\alpha_{L}\right), \mathrm{cm}$ & 4.6 & 1.8 & 2.3 \\
\hline
\end{tabular}


(A)

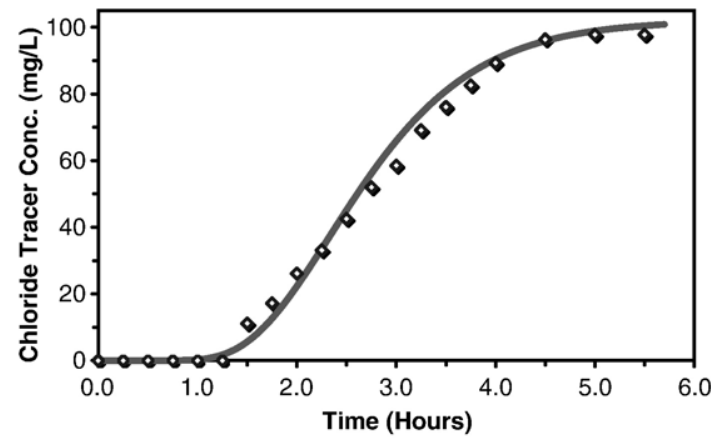

(B)

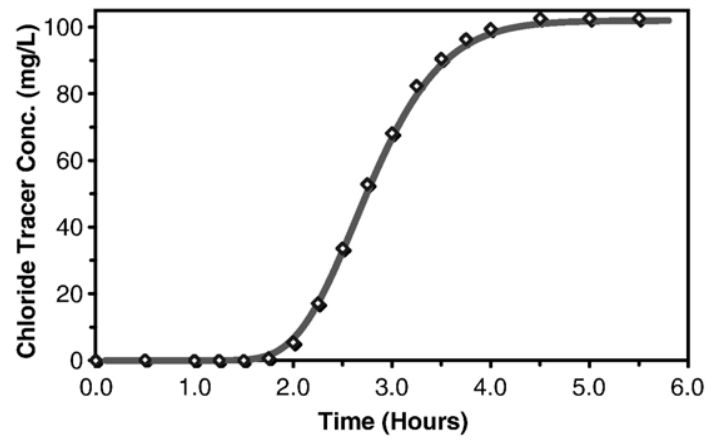

(C)

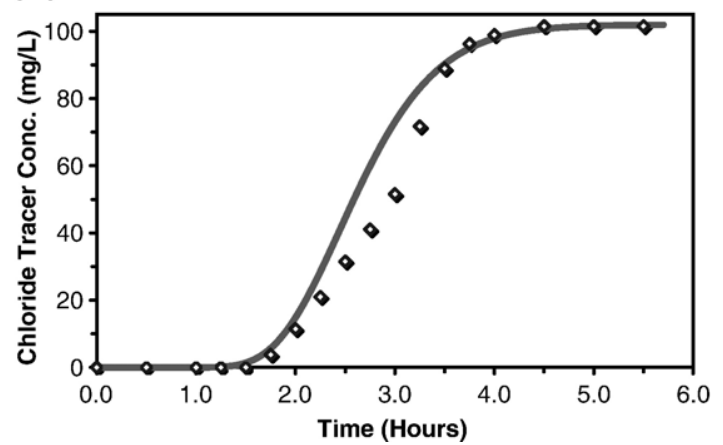

Fig. 3. Tracer test curve data and best-fit model curves (Eqs. (1) and (2)) for the 3 mulch/pea gravel packed columns, (A) Column M1 (longitudinal dispersivity $\left.\left[\alpha_{L}\right]=4.6 \mathrm{~cm}\right)$, (B) Column M2 $\left(\alpha_{L}=1.8 \mathrm{~cm}\right)$, and (C) Column M3 $\left(\alpha_{L}=2.3 \mathrm{~cm}\right)$.

RDX (below the $5 \mu \mathrm{g} / \mathrm{L}$ or ppb MDL) in two out of the three columns, the sampling and analysis frequency was increased. Note that the 10- and 20-pore volume results were further verified using UV-VIS spectral confirmation methods. Also, analyses of samples from the 20-pore volume samples demonstrated a complete removal of RDX in all three columns. The experiment was stopped at the 44-pore volume mark when consistent bed profiles had been obtained for 3 sampling events (i.e., 20-, 37-, and 44-pore volumes). Samples from the 30-pore volume sampling event were not used in the steady state analysis because of poor RDX recoveries resulting from lower sample volumes. 
Steady state was conclusively established by determining pseudo-first-order column rate constants $(k)$ for consecutive sampling events using a curve fitting exercise involving Eq. (3). Regression analysis was performed on all curve-fits attempted and only the model curves that "best fit" (i.e., highest correlation coefficient) the empirical column bed profile were used for comparison purposes. The $k$ values generated for the 44- and 37-pore volume sampling events were identical for

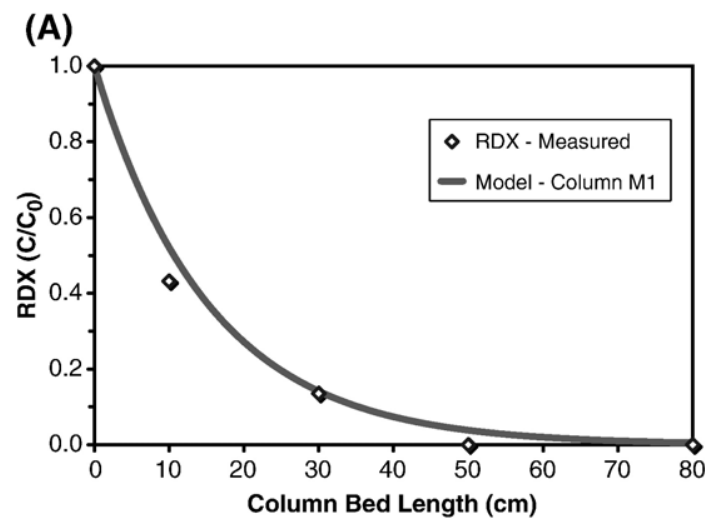

(B)

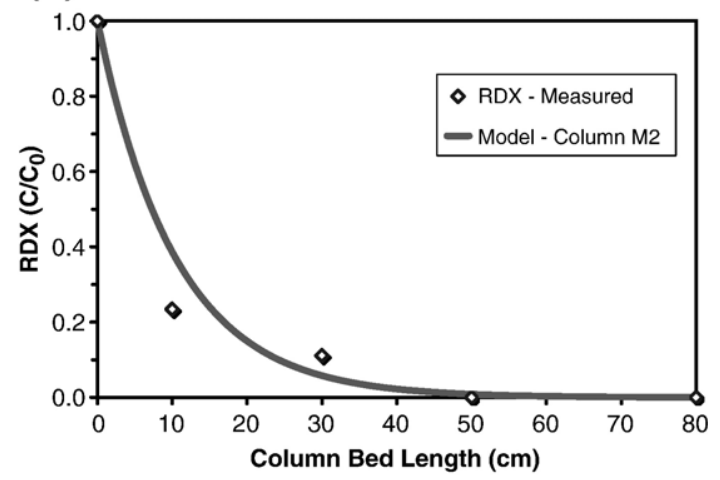

(C)

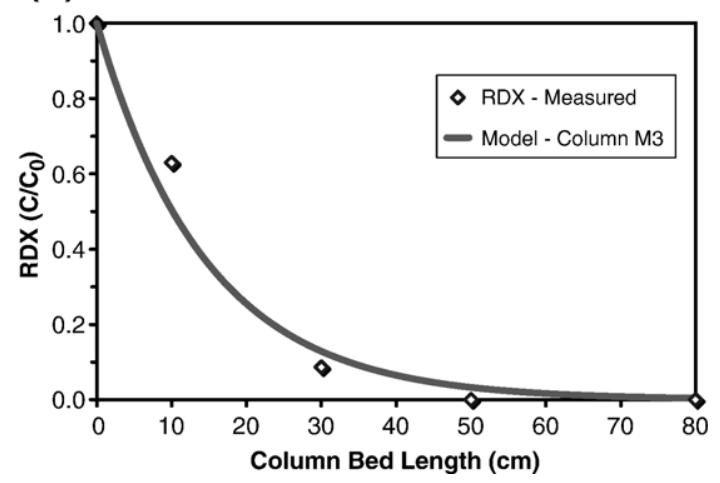

Fig. 4. Steady-state bed profile data and best-fit Eq. (3) model curves for the 3 mulch/pea gravel packed columns, (A) Column M1 (first order degradation rate constant $[k]=0.21 / \mathrm{h}$; correlation coefficient $\left[r^{2}\right]=0.99$ ), (B) Column M2 $\left(k=0.27 / \mathrm{h} ; r^{2}=0.97\right)$, and (C) Column M3 $\left(k=0.20 / \mathrm{h} ; r^{2}=0.98\right)$. 
columns M1 and M2 (0.21 and $0.27 / \mathrm{h}$ for M1 and M2, respectively). Only the $k$ value for column M3 improved slightly (i.e., from 0.20 to 0.21 - a 5\% increase) from 37-PV to the 44-PV sampling event. The column profiles at steady state are presented in Fig. 4A through $C$ for columns M1 through M3, respectively. Note that the figures show data from the 37-pore volume event.

The final $k$ values estimated from the modeling, together with key steady state parameters for each column are presented in Table 5. In general, the column effluent displayed a $-304 \mathrm{mV}$ mean redox and mildly acidic $\mathrm{pH}$ at steady state. Table 5 also lists column lengths (or potential PRB thicknesses) of M1-M3 that will remove $99 \%$ of influent aqueous RDX for each column at steady-state. These values are based on the fitted model from Eq. (3). Similar values calculated using Eq. (4) are also shown. As mentioned earlier and as displayed in Table 5, the true PRB thickness values generated using Eq. (3), which accounts for dispersion, can be significantly higher $(>15 \%$ in the case of Column M1, where the longitudinal dispersivity was $6 \%$ of the bedlength) than those generated using Eq. (4). However, the discrepancy in the calculation of required $\mathrm{PRB}$ thicknesses is much lower ( $7 \%$ or less) when the longitudinal dispersivity is $<3 \%$ of the column-bed length, as in the case of Columns M2 and M3.

As expected, during the transient operation of the columns the control column displayed steadily diminishing removal of RDX owing to non-equilibrium conditions; removal was measured at $27 \%$ of the influent mass at 10 -pore volumes and decreased to $8 \%$ by the 37 -pore volume mark, and was steady after then. In contrast to the control, a 100\% removal of RDX was observed in all 3 mulch columns at the 37-pore volume steady-state mark. Moreover, less than $2 \mu \mathrm{g} / \mathrm{L}$ or ppb loss in the RDX concentration was observed in the influent RDX-spiked groundwater reservoirs over the course of the experiment. Note that the Drum 1 reservoir was in use during the first two sampling rounds, while the Drum 2 reservoir was in use during the next three sampling rounds.

After the confirmation of steady state conditions, large volume (i.e., $>500 \mathrm{~mL}$ ) samples were collected from the effluent line of each column. The samples were collected in parallel into individual 1-L amber-colored bottles over a period of 1.5 days. These samples were analyzed using the standard solid phase extraction/pre-concentration procedure of Method SW-8330M, which yielded detection limits of $0.1 \mathrm{ppb}$ for RDX. Results from this analysis are presented in Table 6 . Using the more sensitive method, no RDX was detected in the column effluents. However, there were trace detections of RDX reduction intermediates, MNX and DNX, in columns M1 and M2. Considering the $87.1 \mu \mathrm{g} / \mathrm{L}$ mean influent RDX concentration, these metabolites constitute a $1-2 \%$ partially treated mass fraction of the influent RDX. In a field setting, these trace metabolites are likely to be treated downgradient of the mulch wall in an anaerobic zone created by the 10 -fold increase in steady-state dissolved TOC concentration in the barrier effluent (compare values in Tables 1 and 5).

Table 5

Final steady-state parameters and modeled kinetic values for the mulch/pea gravel packed columns, M1, M2, and M3

\begin{tabular}{|c|c|c|c|c|c|}
\hline Parameter & $\begin{array}{l}\text { Column } \\
\text { M1 }\end{array}$ & $\begin{array}{l}\text { Column } \\
\text { M2 }\end{array}$ & $\begin{array}{l}\text { Column } \\
\text { M3 }\end{array}$ & Mean & S.D. \\
\hline Seepage velocity $\left(v_{x}\right), \mathrm{cm} / \mathrm{h}$ & 2.48 & 2.43 & 2.53 & 2.48 & 0.05 \\
\hline Pseudo 1 st order rate constant $(k), \mathrm{h}^{-1}$ & 0.21 & 0.27 & 0.20 & 0.23 & 0.04 \\
\hline Correlation coefficient $\left(r^{2}\right)$ & 0.99 & 0.97 & 0.98 & - & - \\
\hline Steady-state TOC in Effluent, $\mathrm{mg} / \mathrm{L}$ & 27.5 & 34.4 & 27.9 & 29.9 & 3.9 \\
\hline Steady-state Effluent $\mathrm{pH}$ & 6.47 & 6.56 & 6.79 & 6.61 & 0.17 \\
\hline Steady-state effluent oxidation-reduction potential (ORP), mV & -297 & -331 & -285 & -304 & 24 \\
\hline $\begin{array}{l}\text { Eq. (3): Required Thickness }(x) \text { for } 99 \% \text { removal }\left(C / C_{0}=0.01\right) \text {, } \\
\text { cm }\end{array}$ & 64.5 & 44.3 & 61.5 & - & - \\
\hline Eq. (4): required thickness $(x)$ for $99 \%$ removal $\left(C / C_{0}=0.01\right), \mathrm{cm}$ & 54.4 & 41.4 & 58.3 & - & - \\
\hline
\end{tabular}


Table 6

Steady-state RDX, HMX, and (RDX) metabolite results for high-volume column effluent samples collected from the mulch/pea gravel packed columns, M1, M2, and M3 (Method Detection Limit [MDL] of $0.1 \mu \mathrm{g} / \mathrm{L}$ or ppb all compounds shown)

\begin{tabular}{lllll}
\hline Parameter & Column M1 & Column M2 & Column M3 & Units \\
\hline RDX & ND & ND & ND & $\mu \mathrm{g} / \mathrm{L}$ \\
MNX & 1.0 & 0.8 & ND & $\mu \mathrm{g} / \mathrm{L}$ \\
DNX & ND & 0.7 & ND & $\mu \mathrm{g} / \mathrm{L}$ \\
TNX & ND & ND & ND & $\mu \mathrm{g} / \mathrm{L}$ \\
HMX & ND & ND & ND & $\mu \mathrm{g} / \mathrm{L}$ \\
\hline
\end{tabular}

Two column-bed (solid) samples were removed from column M2 once the continuous-flow experiment had been concluded after reaching steady-state. These solid samples were subjected to direct analysis by Method SW-8330M, following sample drying. The direct solids analysis showed that no heterocyclic nitramines explosives (i.e., RDX and HMX) or their reduction intermediates (i.e., MNX, DNX, and TNX) were present at a detection limit of $0.1 \mathrm{mg} / \mathrm{kg}$ or ppm. This finding validated earlier findings of poor sorption of RDX to organic-rich solid materials (Pennington et al., 2001). This finding also demonstrates that the pseudo-first-order removal coefficients obtained from the kinetics test were largely a result of a mechanism of degradation rather than sorption.

\subsection{Post-steady-state waste characterization of column fill material}

Two bed solids samples from column M2 were subjected to TCLP analysis for waste characterization, following sample drying. RDX, HMX, MNX, DNX, and TNX were not detected at the $0.1 \mu \mathrm{g} / \mathrm{L}$ or ppb detection limit in the TCLP leachate of the solid samples. In a field remediation setting, the results signify that leaving the mulch PRB material in-place following groundwater treatment is unlikely to pose a contamination risk to clean groundwater once the groundwater remediation has been completed.

\section{Conclusions}

All 5 objectives of the study, listed earlier in the Introduction section were met. Key findings included: (1) columns packed with a 70\%:30\% (volume:volume) mulch:pea gravel mixture were effective at completely removing RDX and HMX from the 20-pore volume mark; (2) pseudofirst-order rate constants for RDX removal at steady-state ranged from $0.20 / \mathrm{h}$ to $0.27 / \mathrm{h}$; (3) from a mean influent RDX concentration of $87.1 \mu \mathrm{g} / \mathrm{L}$ or ppb, no RDX was not detected in the column effluents at the method detection limit of $0.1 \mathrm{ppb}$, well below the Colorado regulatory cleanup level of $0.55 \mathrm{ppb}$; (4) accumulation of RDX intermediates in the steady-state column effluent was $<2 \%$ of the influent RDX mass; and, (5) no RDX, HMX, or RDX reduction intermediates (i.e., MNX, DNX, TNX) were detected in column-bed samples or in the TCLP extracts of these samples.

Key future considerations for an implementation of a mulch PRB at the selected site in Colorado will likely include the following:

1. Hydraulic controls: The 70\%:30\% (volume:volume) mulch:pea gravel mixture selected for the study and the field implementation yields a hydraulic conductivity that is approximately one- 
third of the hydraulic conductivity of the surrounding groundwater-bearing formation. Therefore, field implementation of a mulch/gravel PRB will involve groundwater flow modeling and the installation of hydraulic controls in order to ensure adequate plume capture.

2. PRB thickness: PRB thickness will be recalculated using Eq. (3) once a hydraulically suitable location is selected in the plume. Influent RDX concentrations to the PRB will vary with location within the RDX/HMX plume.

3. Organic mulch selection: Mulch from vendors local to site will be tested for forage and nutrient content (Table 2). Results from these analyses will be matched to results of the mulch used in the study in order to ensure similar RDX degradation performance.

\section{Acknowledgements}

This work was funded by the Environmental Security and Technology Certification Program (ESTCP) under Project No. ER-0426. Key project team members include Dr. Andrea Leeson, Dr. Hans Stroo, and Ms. Erica Becvar. Help with site selection and the collection of site media was provided by Mr. Stan Wharry of the Pueblo Chemical Depot and Mr. Lance Preuss of EartTech Inc. The laboratory treatability study described herein was setup with the assistance of Professor Pedro Alvarez and Dr. Marcio DaSilva of Rice University, and Mr. Travis McGuire of Groundwater Services, Inc.

\section{References}

Ahmad, F., Hughes, J.B., 2000. Anaerobic Transformation of TNT by Clostridium. In: Spain, J.C., Hughes, J.B., Knackmuss, H.-J. (Eds.), Biodegradation of Nitroaromatic Compounds and Explosives. Lewis Publishers/CRC Press, Boca Raton, pp. 185-212.

Ahmad, F., Hughes, J.B., 2002. Reactivity of partially reduced arylhydroxylamine and nitrosoarene metabolites of 2,4,6trinitrotoluene (TNT) towards biomass and humic acids. Environ. Sci. Technol. 36, 4370-4381.

ATSDR, 1996. ToxFAQs: RDX (CAS No. 121-82-4).

Aziz, C.E., Hampton, M.M., Schipper, M.R., Haas, P., 2001. Organic mulch biowall treatment of chlorinated solventimpacted groundwater. Sixth International Battelle In Situ and On-site Bioremediation Symposium. Battelle Press, San Diego, CA.

Bohn, H.L., McNeal, B.L., O’Connor, G.A., 2002. Soil Chemistry. John Wiley \& Sons, New York.

Bowen, H.J.M., 1979. Environmental Chemistry of the Elements. Academic Press, London.

Brady, N.C., 1974. The Nature and Properties of Soils. Macmillan, New York. 12-15 pp.

Charbeneau, R.J., 2000. Groundwater Hydraulics and Pollutant Transport. Prentice-Hall, Upper Saddle River, NJ. 366-378 pp.

Cresser, M.A., Killham, K., Edwards, T., 1993. Soil Chemistry and Its Applications. Cambridge University Press, Cambridge. 100-107 pp.

Davis, J., Hansen, L.D., O’Neal, B., 2001. The effect of ubiquitous electron acceptors on the initiation of RDX biodegradation. In: Magar, V.S., Johnson, G., Ong, S.K., Leeson, A. (Eds.), The Sixth International In Situ and On-Site Bioremediation Conference. Battelle Press, San Diego, California, pp. 43-49.

Duryea, M.L., English, R.J., Hermansen, L.A., 1999. A comparison of landscape mulches: chemical, alleopathic, and decomposition properties. J. Arboric. 25, 88-97.

Ederer, M.M., Lewis, T.A., Crawford, R.L., 1997. 2,4,6-Trinitrotoluene (TNT) transformation by clostridia isolated from a munition-fed bioreactor: comparison with non-adapted bacteria. J. Ind. Microbiol. Biotech. 18, 82-88.

Fetter, C.W., 1999. Contaminant Hydrogeology. Prentice-Hall, Upper Saddle River, NJ. 135-144 pp.

Gavaskar, A.R., Gupta, N., Sass, B.M., Janosy, R.J., O’Sullivan, D., 1998. Permeable Barriers for Groundwater Remediation: Design, Construction, and Monitoring. Battelle Press, Columbus, OH. 29-41 pp.

Gavaskar, A., Gupta, N., Sass, B., Janosy, R., Hicks, J., 2000. Design Guidance for Application of Permeable Reactive Barriers for Groundwater Remediation. SERDP F08637-95-D-6004/5503. Battelle, Colombus, OH.

Hansen, L.D., Davis, J.L., Escalon, L., 2001. Reductive transformation of RDX in a bench-scale simulated aquifer. In: Magar, V.S., Johnson, G., Ong, S.K., Leeson, A. (Eds.), The Sixth International In Situ and On-Site Bioremediation Conference. Battelle Press, San Diego, California, pp. 51-58. 
Hawari, J., et al., 2000. Characterization of metabolites during biodegradation of hexahydro-1,3,5-trinitro-1,3,5-triazine (RDX) with municipal anaerobic sludge. Appl. Environ. Microbiol. 66, 2652-2657.

Heaston, M.S., Barnes, P.W., Alvestad, K.R., 2001. Reductive biotransformation of nitrate and explosives compounds in groundwater. In: Magar, V.S., Johnson, G., Ong, S.K., Leeson, A. (Eds.), The Sixth International In Situ and On-Site Bioremediation Conference. Battelle Press, San Diego, California, pp. 17-24.

Leschine, S., 2005. Degradation of Polymers: Cellulose, Xylan, Pectin, Starch. In: Durre, P. (Ed.), Handbook on Clostridia. Taylor \& Francis/CRC, Boca Raton, pp. 101-131.

Lovely, D.R., 2001. Reduction of iron and humics in subsurface environments. In: Fredrickson, J.K., Fletcher, M. (Eds.), Subsurface Microbiology and Biogeochemistry. John Wiley \& Sons, New York, pp. 193-217.

Lynd, L.R., Weimer, P.J., vanZyl, W.H., Pretorius, I.S., 2002. Microbial cellulose utilization: fundamentals and biotechnology. MMBR 66 (3), 506-577.

McCormick, N.G., Cornell, J.H., Kaplan, A.M., 1981. Biodegradation of hexahydro-1,3,5-trinitro-1,3,5-triazine. Appl. Environ. Microbiol. 42, 817-823.

Melillo, J.M., Aber, J.D., Muratore, J.F., 1982. Nitrogen and lignin control of hardwood leaf litter decomposition dynamics. Ecology 63 (3), 621-626.

Oh, B.-T., Just, L., Alvarez, P.J.J., 2001. Hexahydro-1,3,5-trinitro-1,3,5-triazine mineralization by zerovalent iron and mixed anaerobic cultures. Environ. Sci. Technol. 35, 4341-4346.

Pennington, J.C., et al., 2001. Monitored natural attenuation of explosives. Soil Sed. Contam. 10 (1), 45-70.

Perlmutter, M.W., Britto, R., Cowan, J.D., Patel, M., Craig, M., 2000. Innovative technology: in situ biotreatment of perchlorate-contaminated groundwater. Air and Waste Management Association, 93rd Annual Conference and Exhibition, Salt Lake City, UT.

Regan, K.M., Crawford, R.L., 1994. Characterization of Clostridium bifermentans and its biotransformation of 2,4,6trinitrotoluene and 1,3,5-triaza-1,3,5-trinitrocyclohexane (RDX). Biotechnol. Lett. 16, 1081-1086.

Robertson, W.D., Blowes, D.W., Ptacek, C.J., Cherry, J.A., 2000. Long-term performance of in situ reactive barriers for nitrate remediation. Ground Water 38 (5), 689-695.

Sauty, J.-P., 1980. An analysis of hydrodispersive transfer in aquifers. Water Resour. Res. 16 (1), $145-158$.

Schacklette, H.T., Boerngen, J.G., 1984. Element concentrations in soils and other surficial materials of the coterminous United States. 1270 (Professional Paper), U. S. Geological Survey (USGS).

Schoemaker, H.E., Harvey, P.J., Bowen, R.M., Palmer, J.M., 1985. On the mechanism of enzymatic lignin breakdown. FEBS Lett. 183 (1), 7-12.

Sheremata, T.W., et al., 1999. Fate of 2,4,6-trinitrotoluene and its metabolites in natural and model soil systems. Environ. Sci. Technol. 33, 4002-4008.

Singh, J., Comfort, S.D., Shea, P.J., 1999. Iron-mediated remediation of RDX-contaminated water and soil under controlled Eh/pH. Environ. Sci. Technol. 33, 1488-1494.

Spanggord, R.J., et al., 1980. Environmental fate studies on certain munition wastewater constituents. Final Report Phase I: Literature Review. U. S. Army Medical Research and Development Command, Fort Detrick, Maryland.

Sposito, G., 1989. The Chemistry of Soils. Oxford University Press, New York. 6 pp.

St.John, J., 1998. Tests Reveal Chemicals Flow to Another Site, Cape Cod Times, Fallmouth.

USEPA, 1998. Permeable Reactive Barrier Technologies for Contaminant Remediation. EPA/600/R-98/125.

Vanderloop, S.L., Suidan, M.T., Berchtold, S.R., Moteleb, M.A., Maloney, S.W., 1997. Effects of molecular oxygen on GAC adsorption of energetics. Water Sci. Technol. 35, 197-204.

vanGenuchten, M.T., Alves, W.J., 1982. Analytical solutions of the one-dimensional convective-dispersive solute transport equation. Technical Bulletin. U.S. Dept. of Agriculture, p. 1661.

Wani, A.H., O’Neal, B.R., Davis, J.L., Hansen, L.D., 2002. Environmental security technology certfication program: treatability study for Biologically Active Zone Enhancement (BAZE) for in situ RDX degradation in groundwater. ERDC/ EL TR-02-35. US Army Corps of Engineers, Engineer Research and Development Center (ERDC), Vicksburg, MS.

Zhang, C., Hughes, J.B., 2002. Biodegradation pathways of hexahydro-1,3,5-trinitro-1,3,5-triazine (RDX) by Clostridium acetobutylicum cell-free extract. Chemosphere 50, 665-671. 